\title{
Exploring the Ecology of Bifidobacteria and Their Genetic Adaptation to the Mammalian Gut
}

\author{
Sabrina Duranti ${ }^{1,+}\left(\mathbb{D}\right.$, Giulia Longhi ${ }^{1,2,+}$, Marco Ventura ${ }^{1,3}$, Douwe van Sinderen ${ }^{4}$ and Francesca Turroni ${ }^{1,3, *(\mathbb{D})}$ \\ 1 Laboratory of Probiogenomics, Department of Chemistry, Life Sciences and Environmental Sustainability, \\ University of Parma, Parco Area delle Scienze 11a, 43124 Parma, Italy; sabrina.duranti@unipr.it (S.D.); \\ giulia.longhi@unipr.it (G.L.); marco.ventura@unipr.it (M.V.) \\ 2 GenProbio srl, 43124 Parma, Italy \\ 3 Microbiome Research Hub, University of Parma, 43124 Parma, Italy \\ 4 APC Microbiome Institute and School of Microbiology, Bioscience Institute, National University of Ireland, \\ H91 TK33 Cork, Ireland; d.vansinderen@ucc.ie \\ * Correspondence: francesca.turroni@unipr.it; Tel.: +39-521-905666; Fax: +39-521-905604 \\ + These authors contributed equally.
}

Citation: Duranti, S.; Longhi, G.; Ventura, M.; van Sinderen, D.; Turroni, F. Exploring the Ecology of Bifidobacteria and Their Genetic Adaptation to the Mammalian Gut. Microorganisms 2021, 9, 8. https://dx.doi.org/10.3390/ microorganisms 9010008

Received: 3 December 2020

Accepted: 18 December 2020

Published: 22 December 2020

Publisher's Note: MDPI stays neutral with regard to jurisdictional claims in published maps and institutional affiliations.

Copyright: () 2020 by the authors. Licensee MDPI, Basel, Switzerland. This article is an open access article distributed under the terms and conditions of the Creative Commons Attribution (CC BY) license (https: / creativecommons.org/ licenses/by/4.0/).

\begin{abstract}
The mammalian gut is densely inhabited by microorganisms that have coevolved with their host. Amongst these latter microorganisms, bifidobacteria represent a key model to study host-microbe interaction within the mammalian gut. Remarkably, bifidobacteria naturally occur in a range of ecological niches that are either directly or indirectly connected to the animal gastrointestinal tract. They constitute one of the dominant bacterial members of the intestinal microbiota and are among the first colonizers of the mammalian gut. Notably, the presence of bifidobacteria in the gut has been associated with several health-promoting activities. In this review, we aim to provide an overview of current knowledge on the genetic diversity and ecology of bifidobacteria. Furthermore, we will discuss how this important group of gut bacteria is able to colonize and survive in the mammalian gut, so as to facilitate host interactions.
\end{abstract}

Keywords: Bifidobacterium; microbial ecology; microbe-host interaction; microbe-microbe interaction

\section{History and Taxonomy of Bifidobacteria}

The Actinobacteria phylum represents one of the most numerous and heterogeneous groups of microorganisms present in nature [1,2]. These Gram-positive bacteria are characterized by a high GC genome content ranging from $51 \%$ to more than $70 \%$, and exhibit different morphologies, including unicellular cocci or rods, and complex multicellular consortia [1,2]. Furthermore, these bacteria are able to produce bioactive natural compounds and these features are reflected in their ability to adapt to several quite distinct ecosystems such as various terrestrial and aquatic environments, as well as the bodies of mammals and birds [1,2]. In fact, this phylum includes pathogens (e.g., Mycobacterium spp., Nocardia spp., Tropheryma spp., Corynebacterium spp., and Propionibacterium spp.), soil inhabitants such as Streptomyces spp., plant commensals (e.g., Leifsonia spp.), nitrogen-fixing symbionts (Frankia), and human gut inhabitants (Bifidobacterium spp.) [1,2].

The genus Bifidobacterium belongs to the Bifidobacteriaceae family, Bifidobacteriales order, and these bacteria were isolated, for the first time, from feces of a breast-fed infant by Tissier in 1899 [3]. They represent nonmotile, anaerobic, nonsporulating, saccharolytic bacteria with a bifid or multiple-branching rod morphology. Currently, the genus Bifidobacterium comprises 94 taxa, representing 82 species and 12 subspecies [4-12] (Table 1). In recent years, the phylogeny of the Bifidobacterium genus has been explored using different methods based on the sequencing of the 16S rRNA gene, by means of a multilocus approach, or the sequencing of several housekeeping genes (i.e., $c l p C$, dnaJ, rpoC, $x p f$, dnaB, and purF) [13,14]. A comparative genomics analysis based on all 88 sequenced 
bifidobacterial type strains revealed the presence of 191 Bifidobacterium-specific clusters of orthologous genes (COGs) shared by these genomes, called the bifidobacterial coregenome [15]. Notably, the phylogenetic tree constructed by amino acid concatenation of these 191 bifidobacterial core-genome genes revealed the existence of 10 different phylogenetic groups, encompassing Bifidobacterium adolescentis, Bifidobacterium boum, Bifidobacterium pullorum, Bifidobacterium asteroides, Bifidobacterium longum, Bifidobacterium psychraerophilum, Bifidobacterium bifidum, Bifidobacterium pseudolongum, Bifidobacterium bombi, and Bifidobacterium tissieri groups [15]. These groups partially correlate with the ecological niches from which the representative species were isolated. For example, members of the B. tissieri group are common inhabitants of the microbiota of tamarin and those of the B. pullorum group are characteristic of birds. According to this, members of the $B$. adolescentis group (Bifidobacterium catenulatum, Bifidobacterium pseudocatenulatum, and B. adolescentis strains), the B. longum group (Bifidobacterium breve and B. longum strains), the B. pseudolongum group (especially Bifidobacterium animalis subsp. lactis strains), and the B. bifidum group (B. bifidum strains) are typical colonizers of the human intestinal tract or are commercially exploited as probiotic strains (Figure 1).

Table 1. Bifidobacterium (sub)species recognized as reference strains (type strains).

\begin{tabular}{|c|c|c|}
\hline Bifidobacterium Strains & Isolation & References \\
\hline B. actinocoloniiforme DSM 22766 & Bumblebee digestive tract & [16] \\
\hline B. adolescentis ATCC 15703 & Intestine of human adult & {$[17]$} \\
\hline B. aemilianum XV10 & Carpenter bee digestive tract & {$[5]$} \\
\hline B. aerophilum DSM 100689 & Feces of cotton-top tamarin & [18] \\
\hline B. aesuclapii DSM 26737 & $\begin{array}{c}\text { Feces of baby common } \\
\text { marmoset }\end{array}$ & [19] \\
\hline B. angulatum LMG 11039 & Feces of human & [20] \\
\hline B. animalis subsp. animalis LMG 10508 & Feces of rat & {$[21]$} \\
\hline B. animalis subsp. lactis DSM 10140 & Fermented milk & [22] \\
\hline B. anseris LMG 30189 & Feces of domestic goose & [7] \\
\hline B. apri DSM 100238 & Digestive tract of wild pig & [23] \\
\hline B. aquikefiri LMG 28769 & Water kefir & [24] \\
\hline B. asteroides LMG 10735 & Hindgut of honeybee & [25] \\
\hline B. avesanii DSM 100685 & Feces of cotton-top tamarin & [18] \\
\hline B. biavatii DSM 23969 & Feces of tamarin & [26] \\
\hline B. bifidum LMG 11041 & Feces of breast-fed infant & [3] \\
\hline B. bohemicum DSM22767 & Bumblebee digestive tract & [16] \\
\hline B. bombi DSM 19703 & Bumblebee digestive tract & [27] \\
\hline B. boum LMG 10736 & Rumen of bovine & [28] \\
\hline B. breve LMG 13208 & Infant stool & [17] \\
\hline B. callimiconis LMG 30938 & Feces of Goeldi's marmoset & {$[6]$} \\
\hline B. callitrichidarum DSM 103152 & Feces of emperor tamarin & [29] \\
\hline B. callitrichos DSM 23973 & Feces of common marmoset & [26] \\
\hline B. canis DSM105923 & Feces of dog & [10] \\
\hline B. castoris LMG 30937 & Feces of beaver & [6] \\
\hline B. catenulatum LMG 11043 & Adult intestine & {$[30]$} \\
\hline $\begin{array}{l}\text { B. catenulatum subsp. kashiwanohense } \\
\text { DSM21854 }\end{array}$ & Infant feces & [31] \\
\hline B. catulorum DSM103154 & Feces of common marmoset & {$[32]$} \\
\hline B. cebidarum LMG31469 & $\begin{array}{l}\text { Feces of golden-headed } \\
\text { tamarin }\end{array}$ & [9] \\
\hline B. choerinum LMG 10510 & Feces of piglet & [28] \\
\hline B. commune LMG28292 & Bumblebee gut & [33] \\
\hline B. coryneforme LMG 18911 & Hindgut of honeybee & [25] \\
\hline B. criceti LMG 30188 & Feces of European hamster & [7] \\
\hline B. crudilactis LMG 23609 & Raw cow milk & [34] \\
\hline B. cuniculi LMG 10738 & Feces of rabbit & [28] \\
\hline B. dentium LMG 11045 & Oral cavity & {$[30]$} \\
\hline
\end{tabular}


Table 1. Cont.

\begin{tabular}{|c|c|c|}
\hline Bifidobacterium Strains & Isolation & References \\
\hline B. dolichotidis LMG 30941 & Feces of Patagonian mara & [6] \\
\hline B. eulemuris DSM 100216 & Feces of black lemur & [35] \\
\hline B. felsineum DSM103139 & Feces of cotton-top tamarin & [11] \\
\hline B. gallicum LMG 11596 & Adult intestine & [36] \\
\hline B. goeldii LMG 30939 & Feces of Goeldi's marmoset & [6] \\
\hline B. hapali DSM 100202 & $\begin{array}{l}\text { Feces of baby common } \\
\text { marmoset }\end{array}$ & [37] \\
\hline B. imperatoris LMG 30297 & Feces of emperor tamarin & [7] \\
\hline B. indicum LMG 11587 & Insect & [25] \\
\hline B. italicum LMG 30187 & Feces of European rabbit & [7] \\
\hline B. jacchi DSM 103362 & $\begin{array}{l}\text { Feces of baby common } \\
\text { marmoset }\end{array}$ & [38] \\
\hline B. lemurum DSM 28807 & Feces of ring-tailed lemur & [39] \\
\hline B. leontopitechi LMG 31471 & Feces of Goeldi's monkey & [9] \\
\hline B. longum subsp. infantis ATCC 15697 & Intestine of infant & [17] \\
\hline B. longum subsp. longum LMG 13197 & Adult intestine & [17] \\
\hline B. longum subsp. suis LMG 21814 & Feces of pig & [40] \\
\hline B. magnum LMG 11591 & Feces of rabbit & [30] \\
\hline B. margollesii LMG 30296 & Feces of pygmy marmoset & [7] \\
\hline B. meryciucm LMG 11341 & Rumen of bovine & [41] \\
\hline B. minimum LMG 11592 & Sewage & [42] \\
\hline B. mongoliense DSM 21395 & Fermented mare's milk & [43] \\
\hline B. moukabalense DSM 27321 & Feces of gorilla & [44] \\
\hline B. myosotis DSM 100196 & Feces of common marmoset & [37] \\
\hline B. parmae LMG 30295 & Feces of pygmy marmoset & [7] \\
\hline B. platyrrhinorum SMA15 & Feces of squirrel monkey & [45] \\
\hline B. primatium DSM 100687 & Feces of cotton-top tamarin & [11] \\
\hline B. pseudocatenulatum LMG 10505 & Infant feces & {$[28]$} \\
\hline B. pseudolongum subsp. globosum LMG 11596 & Rumen of bovine & [46] \\
\hline $\begin{array}{c}\text { B. pseudolongum subsp. pseudolongum LMG } \\
11571\end{array}$ & Feces of swine & [21] \\
\hline B. psychraerophilum LMG 21775 & Caecum of pig & [47] \\
\hline B. pullorum subsp. gallinarum LMG 11586 & Caecum of chicken & [48] \\
\hline B. pullorum subsp. pullorum LMG 21816 & Feces of chicken & [8] \\
\hline B. ramosum DSM 100688 & Feces of cotton-top tamarin & [18] \\
\hline B. reuteri DSM 23975 & Feces of common marmoset & [26] \\
\hline B. rousetti BCRC 81136 & Feces of Egyptian fruit bat & [49] \\
\hline B. ruminantium LMG 21811 & Rumen of bovine & [41] \\
\hline B. pullorum subsp. saeculare LMG 14934 & Feces of rabbit & [50] \\
\hline B. saguini LMG 23967 & Feces of tamarin & [26] \\
\hline B. saimiriisciurei SMA1 & Feces of squirrel monkey & [45] \\
\hline B. saimirii LMG 30940 & Feces of Bolivian saimiri & [6] \\
\hline B. scaligerum DSM 103140 & Feces of cotton-top tamarin & [11] \\
\hline B. scardovii LMG 21589 & Blood & [51] \\
\hline B. simiarum DSM 103153 & Feces of emperor tamarin & [11] \\
\hline B. stellenboschense DSM 23968 & Feces of tamarin & [26] \\
\hline B. subtile LMG 11597 & Sewage & [42] \\
\hline B. porcinum LMG 21689 & Feces of piglet & [52] \\
\hline B. thermacidophilum LMG 21395 & Anaerobic digester & [53] \\
\hline B. termophilum JCM 7027 & Rumen of bovine & [21] \\
\hline B. tibiigranuli LMG 31086 & Water kefir & [54] \\
\hline B. tissieri DSM 100201 & $\begin{array}{l}\text { Feces of baby common } \\
\text { marmoset }\end{array}$ & [37] \\
\hline B. tsurumiense JCM 13495 & Hamster dental plaque & [55] \\
\hline B. vansinderenii LMG 30126 & Feces of emperor tamarin & [56] \\
\hline B. vespertilionis DSM 106025 & Feces of Egyptian fruit bat & [49] \\
\hline B. xylocopae DSM104955 & Carpenter bee digestive tract & [5] \\
\hline
\end{tabular}




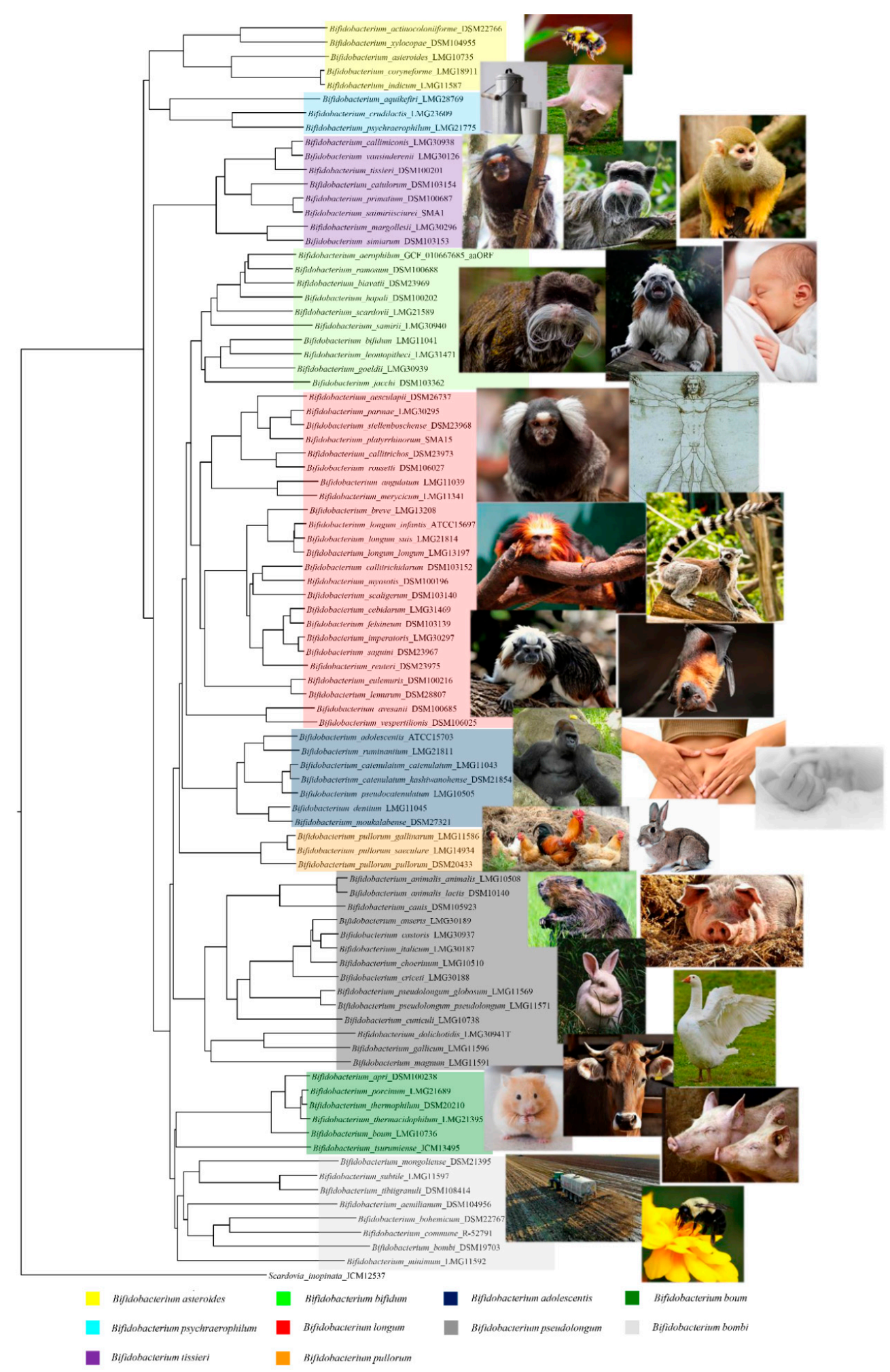

Figure 1. Phylogenetic tree of the Bifidobacterium genus based on the concatenation of 191 core amino acid sequence genes. The core genes-based tree shows the subdivision of the 10 phylogenetic groups of the Bifidobacterium genus represented with different colors. The phylogenetic tree was built by the neighbor-joining method with corresponding sequences of Scardovia inopinata JCM 12,537 being employed as outgroup. Bootstrap percentages above 50 are shown at node points, based on 100 replicates of the phylogenetic tree. The ecological origins of the various phylogenetic groups are highlighted beside the phylogenetic tree. 


\section{Ecology of Bifidobacteria}

Bifidobacteria also naturally occur in the gastrointestinal tract (GIT) of animals, such as nonhuman mammals, insects, and birds [5-11], while they have also been isolated from human blood [51], sewage [42], the oral cavity [55], and fermented milk [15]. In this context, it has been demonstrated that the ability of bifidobacteria to adapt to specific environments is species-dependent [4]. Until recently, scientific studies revealed that B. longum, B. adolescentis, B. pseudolongum, and B. bifidum species possess a cosmopolitan lifestyle [4], whereas other bifidobacterial species appear to be adapted to the GIT of particular animals (e.g., Bifidobacterium cuniculi for rabbits, Bifidobacterium angulatum for cows, and Bifidobacterium gallinarum for chickens) or the human gut (e.g., B. breve and B. longum species) [4,12]. However, recent ecological studies, based on Internally Transcribed Spacer (ITS) profiling, have revealed that the distribution of Bifidobacterium species is not host-specific $[57,58]$. For example, the $B$. breve species, which until that point had only been associated with the human gut, was shown to be present also in domesticated animals [57]. Furthermore, particular species, such as Bifidobacterium actinocoloniiforme, B. asteroides, Bifidobacterium bohemicum, B. bombi, and Bifidobacterium indicum, which were previously thought to be highly specialized to colonize the insect gut, were shown to be widely distributed among various mammalian hosts [58]. Notably, the distribution of bifidobacterial species in different ecological niches reinforces the idea that anthropogenic influences may have promoted such apparent horizontal transmission events.

The Bifidobacterium genus is one of the most abundant bacterial genera present in the human gut during the early stages of life [59-61] and these microorganisms are reported to be among the first bacterial colonizers of the newborn's GIT [62]. It has been demonstrated that bifidobacteria may engage in vertical transmission that occurs between a mother and her newborn during birth and possibly through subsequent breastfeeding [63,64]. This fascinating phenomenon not only occurs in human beings [65] but also in other mammalian species [58]. In this context, some studies have shown how taxonomic classification of bifidobacteria present in the mother's microbiota strongly correlates with that of the infant $[66,67]$. In particular, a study based on ITS-profiling and shotgun-metagenomics approaches has led to the identification of the species shared between a mother and her child [68]. In this study, the microbiota of a mother's fecal and milk samples were assayed together with corresponding infant fecal samples collected at different time points. These analyses demonstrated that in some cases, identical bifidobacterial strains are shared in both mother's and baby's gut microbiota [68]. A B. breve strain and B. longum subsp. longum isolate were seen to be among the protagonists of vertical transmission from mother to child, being found both in the newborn's meconium and in the fecal samples of the child for up to 90 days [68]. Several species of this genus are believed to have undergone specific genetic and metabolic adaptations in order to facilitate colonization of the infant gut, for example, the ability of certain bifidobacterial species and strains to metabolize specific oligosaccharides present in human milk [69]. Specifically, bifidobacterial species that are prevalent in the gut of infants include B. breve, B. longum subsp. infantis, B. longum subsp. longum, B. pseudocatenulatum, and B. bifidum [62], whereas B. adolescentis, B. catenulatum, B. pseudocatenulatum, and B. longum subsp. Longum [70,71] are commonly occurring species in the adult intestine. In this context, it is not fully correct to consider the use of fecal material as a representation of the entire intestinal microbiota. In fact, the fecal microbiota consists not only of mucosal adherent members of the human GIT microbiota but also of transient bacteria derived from the diet or other environmental microbial contaminations [72]. Specifically, only a small number of bifidobacterial species (i.e., B. longum, B. adolescentis, B. breve, B. pseudocatenulatum, and B. pseudolongum) seem to be dominant in the examined biopsies, whereas certain other bifidobacterial species are restricted to a specific ecological niche (e.g., B. bifidum and B. pseudolongum) [73]. Analyses not only of human intestinal mucosal but also of fecal samples have shown that bifidobacterial distribution changes within ages, with a remarkable conservation in terms of species and strains in adults and children [73]. Furthermore, little is known about the diversity of bifidobacterial 
populations occurring between individuals and between different compartments of the GIT within the same individual [73].

The presence of bifidobacteria in the GIT has been associated with various health benefits, including the development of the immune system, protection against pathogens mediated through the process of competitive exclusion, and/or the production of metabolites such as short-chain fatty acids (SCFA) and vitamins [59,62,70,74]. Indeed, humanresidential bifidobacteria (HRB) are also capable of producing folate, also known as vitamin B9 or B11, which is required for an efficient DNA replication, DNA repair/methylation, and synthesis of nucleotides, vitamins, and certain amino acids [75,76]. For these reasons, several bifidobacterial strains/species are used as active ingredients in a variety of so-called functional foods due to their perceived health-promoting or probiotic properties [2]. In this context, probiotic bifidobacterial strains belonging to B. longum and Bifidobacterium animalis subsp. lactis species are usually added to yogurt, other fermented milks, and, more recently, to cheese, which are the most popular probiotic foodstuffs at the moment $[77,78]$. Moreover, clinical studies have demonstrated that $B$. animalis ssp. lactis Bb-12, administered as probiotic adjunctive therapy, have beneficial effects in the case of infectious diarrhea caused by viruses or bacteria $[79,80]$, decreasing the frequency or shortening the duration of the infection and increasing immune responses [81].

\section{Bifidobacteria and Their Genetic Adaptation to the Human Gut}

In silico analysis of bifidobacterial genomes has uncovered molecular evidence illustrating how particular members of this genus have adapted to the human intestine. In particular, analysis of these data identified a large arsenal of genes encoding enzymes involved in the degradation of complex carbohydrates derived from the (mother of the) host (e.g., mucin and human milk oligosaccharides) or from the diet (e.g., starch, galactan, (arabino)xylan) $[69,82,83]$. Specifically, these carbohydrates cannot be digested by host enzymes or metabolized by most microorganisms of the gut microbiota, yet can be utilized by certain gut commensals, which may include bifidobacteria $[82,83]$. Clear examples of bifidobacteria that encode enzymes for host glycan degradation and utilization are B. bifidum PRL2010 and B. longum subsp. infantis ATCC15697 [69,82]. In this context, genome analysis of $B$. bifidum PRL2010 revealed that this strain encodes various enzymes that are responsible for mucin degradation, including a 1,2- $\alpha$-L-fucosidase, a 1,3/4- $\alpha$-L-fucosidase, putative exo- $\alpha$-sialidases, $\mathrm{N}$-acetyl- $\beta$-hexosaminidases, $\beta$-galactosidases, and a putative cell wallanchored endo- $\alpha-\mathrm{N}$-acetylgalactosaminidase [82]. Furthermore, comparative genomic analyses of several B. bifidum strains highlighted that the genetic repertoire involved in mucin breakdown is well conserved in members of this taxon [84]. Moreover, the genome of B. longum subsp. infantis ATCC15697 harbors a genetic locus encompassing genes that encode enzymes involved in Human Milk Oligosaccharides (HMOs) degradation, such as a fucosidase, sialidase, $\beta$-hexosaminidase, and $\beta$-galactosidase [69]. Recently, comparative genome analysis involving two strains of B. longum subsp. infantis (i.e., ATCC15697 and Bi-26) revealed that the metabolic enzymes involved in HMOs utilization appear to be conserved in this bifidobacterial taxon [85]. This comparative analysis was confirmed by metabolite analysis as well as transcriptomics assays suggesting that B. longum subsp. infantis ATCC15697 is able to consume various HMOs simultaneously, whereas B. longum subsp. infantis $\mathrm{Bi}-26$ is adapted to internalize relatively short and predominantly fucosylated HMOs [85]. In conclusion, these findings show that even though HMOs consumption is characteristic of $B$. longum subsp. Infantis, there is strain-level variation concerning the ability of particular strains to metabolize structurally distinct elements from the HMOs pool.

Another significant example of genetic adaptation of bifidobacteria to the human gut is represented by the $B$. adolescentis species, which can utilize certain dietary polymeric carbohydrates, such as resistant starch $[82,83]$. The structurally related glycans starch, amylopectin, and pullulan have previously been demonstrated to be utilized by different bifidobaterial species, such as B. breve and B. adolescentis. In particular, $\mathrm{O}^{\prime}$ Connell Motherway et al., analysing the genome of B. breve UCC2003, have characterized an extracellular 
bifunctional class II amylopullulanase, known as $a p u \mathrm{~B}$, that is crucial for this species to metabolize starch [86]. Specifically, in order to evaluate the activity of this enzyme, the $B$. breve UCC2003 strain was manipulated to generate B. breve UCC2003-apuB mutant [86]. This study showed that the apuB-encoded enzyme is involved in the hydrolysis of extracellular starch or long-chain maltooligosaccharides to produce shorter maltooligosaccharides [86]. Also, various members of the B. adolescentis species possess a genetic repertoire predicted to be involved in the breakdown of starch and starch derivates $[83,87,88]$. In this context, pan-genome analysis of B. adolescentis showed that these enzymes, predicted to represent an $\alpha$-glucosidase, amylase, pullulanase, and cyclomaltodextrinase, and assumed to be required for the degradation of starch and starch-like glycans, are present in all strains analyzed except for B. adolescentis 703B and B. adolescentis JCM15918 [83]. Consistent with this observation is the finding that these two strains do not exhibit any appreciable growth on starch [83]. Notably, none of the genomes of these B. adolescentis strains contain genes involved in the metabolism of host-derived glycans [83]. Altogether, these findings support the notion that there is a specific adaptation of $B$. adolescentis to the adult human gut, where starch represents a substantial glycan part of the diet. In fact, infant-associated Bifidobacterium species, such as B. bifidum and B. longum subsp. infantis, have evolved towards an ecological niche where host-polysaccharides such as mucin and HMOs are present in high abundance, whereas the adult-associated B. adolescentis taxon is adapted to colonize an environment where certain dietary plant-derived glycans are expected to be present.

\section{Example of Host-Bifidobacteria and Microbe-Microbe Interactions in the Human Gut}

Commensal gut bacteria have evolved specific strategies to establish interactions with the human host through various extracellular molecules, which include pili, capsular polysaccharides or exopolysaccharides, and serine protease inhibitors $[4,87,89,90]$. Recent studies have shown that also certain metabolic molecules such as tryptophan-derived metabolites can mediate host-microbe interactions [91,92]. It has been demonstrated that indole-3-lactic acid (ILA) is the main tryptophan-derived metabolite produced by bifidobacteria [93]. ILA is produced in large quantities by certain species of bifidobacteria, such as B. longum subsp. longum, B. longum subsp. infantis, B. breve, and B. bifidum, which are commonly isolated from human infant fecal samples [93]. The precise role played by this metabolite in infant development is not yet clear, but studies have reported that microbial tryptophan metabolites may have a positive effect on inflammatory responses [94] and neurological functions [95], while also maintaining intestinal and systemic homeostasis [96].

The genomes of most bifidobacteria encode two different types of pili, known as the sortase-dependent pili and type IVb or Tad (Tight adherence) pili that are involved in microbe-host interactions [89,97-99]. Specifically, the biosynthetic machinery for sortasedependent pilus production is encoded by a genetic locus that includes a gene encoding a major pilin protein, one or two genes involved in the synthesis of ancillary pilin proteins, and a gene encoding a pilus-specific sortase, implicated in the assembly of pilus subunits [97]. In particular, comparison of genome sequences of various bifidobacterial species highlights the genetic diversity of sortase-dependent pilus-encoding loci within this genus. Specifically, the number of sortase-dependent pilus loci is different between species or even among strains of the same species. For example, the genome of Bifidobacterium dentium $\mathrm{Bd} 1$ is predicted to contain seven sortase-dependent pilus loci, that of $B$. bifidum PRL2010 harbors three putative sortase-dependent pilus loci, while the genomes of B. animalis subsp. lactis DSM10140, B. adolescentis ATCC15703, and B. longum subsp. infantis ATCC15697 revealed the predicted presence of just one such locus [97]. Current knowledge concerning the fimbriome of B. bifidum PRL2010 indicates that sortase-dependent pili play an important role in the establishment and colonization of this strain within the human gut $[97,100,101]$. In this context, Turroni et al. observed that pili produced by B. bifidum PRL2010 are able to induce high levels of TNF- $\alpha$ cytokines, and to reduce the expression of other proinflammatory cytokines (e.g., IL-12). These data support the notion that B. bifidum 
PRL2010, representing one of the first colonizers of the infant gut, is able to modulate the immune system of a newborn. This feature may thus have very important implications for the infant host, whose immature immune system may be dependent on specific stimulatory signals with long-lasting health consequences [98].

Another key example of extracellular structures produced by bifidobacterial species that are known to modulate the interaction with their hosts is represented by the Tad pili, which are conserved in all known bifidobacterial genomes [89,99]. The gene cluster of Tad pili is composed of three domains, including the machinery for pilus formation (i.e., assembly and localization domain, pilin proteins domains, processing domain). In the context of assembly and localization of these extracellular appendages, pilus localization is presumed to be determined by the product of tadZ, while ATPase and pilus assembly activities are encoded by $t a d \mathrm{~B}$ and $t a d \mathrm{G}$. Pilin proteins consist of a pre-pilin precursor, encoded by flp, and minor pilin precursors which are specified by tadE and tadF, while processing of these pilin precursors is performed by a prepilin peptidase, encoded by tadN, which is located outside of the tad locus [102]. Bifidobacterial Tad pili have been characterized in B. breve UCC2003 [99]. In particular, in vitro and in vivo studies revealed that B. breve UCC2003 Tad pili play a key role in gut colonization of the host [99]. In this context, in vivo experiments using a germ-free murine model revealed an increase in host intestinal cell proliferation after five days following the administration of B. breve UCC2003 [103]. Conversely, administration of a B. breve UCC2003 derivative carrying a mutation in the tadE gene to mice showed a significantly lower level of cell proliferation when compared to the control group (where mice were administered the wild-type B. breve strain) [103]. These data identified that the TadE pseudopilin promotes colonic epithelial cell proliferation and growth, confirming that Tad pili produced by B. breve UCC2003 are indeed involved in an important aspect of microbe-host interactions.

Another important factor involved in host-microbe interaction is the bifidobacterial serine protease inhibitor (serpin), which is a member of a superfamily of proteins involved in the regulation of certain protease-mediated processes [104]. Analysis of available bifidobacterial genomes revealed the presence of serpin-encoding genes in just a few human gut-derived bifidobacterial species, in particular B. longum subsp. longum, B. longum subsp. Infantis, and B. breve [105]. In contrast, the genomes of other human gut bifidobacterial species such as B. adolescentis, B. catenulatum, B. bifidum, and B. gallicum do not contain a serpin-encoding gene in their genomes, suggesting that these species are protected from serine proteases through an alternative way or rely on cross-protection offered by (bifido)bacterial species that are able to produce such serpins [105]. The release of serine proteases occurs as a result of intestinal inflammation caused by bacterial infections or damage to the intestinal tissue, typical of inflammatory bowel disease or ulcerative colitis. In this context, self-produced serpins help gut bacteria such as bifidobacteria to protect their extracellular proteins (e.g., pilins or glycan-hydrolyzing enzymes, see above) from degradation by these host-derived proteases, which may be advantageous for colonization and nutrient acquisition purposes $[105,106]$.

An in vitro assay based on cells of B. breve $210 \mathrm{~B}$ treated with different proteases highlighted that transcriptional activation of the serpin gene is guided by specific proteases [105]. In particular, analysis of transcriptional profiling of B. breve $210 \mathrm{~B}$ cells treated with several proteases revealed that papain is able to stimulate upregulation of the serpin-encoding gene locus [105]. Furthermore, Alvarez-Martin et al. demonstrated that transcription of the serpin-encoding gene in B. breve UCC2003 is controlled by a two-component regulatory system (2CRS), known as SerRK [107]. Moreover, data derived from the analysis of B. breve UCC2003-serU mutant experiments highlighted that the SerRK signaling pathway includes a SerU-dependent autoregulatory mechanism [107]. SerU is one of the two genes belonging to the ser2003 locus and encoding a serpin-like protein. This positive autoregulatory loop seems to ensure further production of SerU when the encountered proteolytic activity is higher than the provided serpin-mediated protease inhibition [107]. Bifidobacterial serpins, by the inhibition of human proteases, such as $\alpha$-antitrypsin and human neutrophil elastase, 
are intended to reduce exaggerated serine protease activity, which could otherwise cause pathological damage to tissue [108].

In addition to pili and serpins, other key bifidobacterial extracellular structures that were shown to mediate the interaction with the host are exopolysaccharides (EPSs). The EPS consists of repeated mono or oligosaccharides units linked by glycosidic linkages that may result in a wide variety of structurally distinct macromolecules [109]. Several studies have revealed that surface-associated EPSs of bifidobacteria support gut colonization [110-112]. Furthermore, genomic analysis of 48 bifidobacterial species revealed that all type strains, except for B. bifidum species, contain at least one eps cluster [109]. Across assessed bifidobacterial (sub)species and based on common genetic organization of eps gene clusters, nine distinct eps clusters have been identified. In particular, the eps 1 and eps 2 clusters are found in bifidobacterial taxa commonly isolated from the human intestine, whereas the eps 3 and eps 4 clusters are identified in the genomes of bifidobacterial (sub)species commonly recovered from the gut of various animals [109]. Moreover, the cocultivation of different bifidobacterial strains in fecal media that simulate the human gut of adults as well as infants revealed the upregulation of the genes involved in EPS biosynthesis [109]. Transcriptional regulation of eps genes during growth of bifidobacterial in multi-association showed modulation of EPS biosynthesis by several bifidobacterial taxa when present in the same environment [109]. In recent years, interest in EPS producers has grown due to the key role that they appear to play in promoting human health [113]. Particularly, it has been demonstrated that B. breve UCC2003 produces an EPS which is capable of modulating immune responses and reducing the infection of a gut pathogen [114]. The genome of $B$. breve UCC2003 possesses two sets of adjacent oppositely oriented genes encoding two distinct EPSs, whose expression depends on the orientation of a single promoter. Therefore, only one of the two types of EPSs can be produced at any time [112]. Fanning et al. have demonstrated that splenocytes isolated from naïve mice stimulated with the EPS-producing B. breve UCC2003 strain (EPS+) evoked a lower expression of proinflammatory cytokines compared to two EPS-deficient (EPS-) B. breve UCC2003 strains. This finding was further confirmed by in vivo analysis on mice orally fed with EPS+ and EPS- strains, suggesting that strains producing surface EPS (EPS+) failed to elicit a strong immune response compared with EPS-deficient variants [114]. B. longum subsp. longum 35,624 is another interesting bifidobacterial producer of EPS which was shown to play a key role in modulating the host immune response. Comparative genomic analyses revealed the presence of a gene cluster (eps624) which encodes the EPS biosynthetic machinery, and which, despite its conserved genomic location, exhibits genetic diversity in different B. longum subsp. longum strains [115]. A study based on the coculture of human Peripheral Blood Mononuclear Cells (PBMCs) or Monocyte-derived Dendritic Cells (MDDCs) with B. longum subsp. longum 35,624 and EPS-negative mutant derivative demonstrated that the lack of EPS may increase proinflammatory cytokine secretion [116]. Similarly, administration of these strains to mice as a model of colitis underlined that the EPS-producing strains are able to prevent disease, while the EPS-deficient derivative does not show any protection against the development of colitis [116]. All together, these findings emphasize that the EPS of various bifidobacterial strains plays an important role in reducing the proinflammatory response.

Nowadays, much is known about microbe interactions with the human gut, also thanks to the great importance that bifidobacteria have gained as health-promoting bacteria. Given their wide ecological distribution, the challenge for the future is to deepen the knowledge of this field by studying other bifidobacterial mammalian strains/species as well.

\section{Microbe-Microbe Cross-Feeding Activities Influence Intestinal Immune Homeostasis and Inflammatory Response}

As mentioned above, bifidobacteria are microorganisms which are able to degrade certain complex carbohydrates that are indigestible to the host [74]. Carbohydrate metabolism by gut commensals leads to the production of SCFAs, of which acetate, propionate, and butyrate are most relevant in the context of the human gut. These SCFAs perform key functions such as increasing the absorption of calcium and magnesium, providing nutri- 
ents for the colonocytes, and stimulating the host immune system [117,118]. Among the SCFAs produced in the colon, butyrate represents a compound of high importance and impact for the gut. In fact, it is a source of energy for the intestinal mucosa cells, stimulating their replication [119]. Unable to directly synthesize butyrate, bifidobacteria resort to a mutual beneficial cross-feeding interaction with butyrogenic members of the intestinal microbiota such as Faecalibacterium prausnitzii [120]. In this context, bifidobacteria degrade complex carbohydrates producing acetate, which then becomes a source of energy for secondary degraders, which use acetate to generate butyrate. The cross-feeding interaction is mutually beneficial as both strains benefit from each other's presence through the processing of metabolites favoring the coexistence in the same ecological niche. Bifidobacteria create numerous trophic interactions with each other and with other members of the gut microbiota. It has been demonstrated that cocultivation of B. longum NCC2705 and Eubacterium rectale ATCC 33,656 in a medium rich in arabinoxylo-oligosaccharides (AXOS) positively influences growth of both strains [121]. Specifically, B. longum NCC2705 possesses the enzymes capable of degrading AXOS, resulting in the release of xylose backbone (XOS) and acetate. The latter is used by E. rectale ATCC 33,656 to produce butyrate with consequent butyrogenic effect [121]. Similarly, recent studies have reported various crossfeeding interactions that exist between Bifidobacterium and Bacteroides species [122,123], and Bifidobacterium and F. prausnitzii [124]. In the same manner, other studies have reported potential syntrophic interactions between bifidobacterial strains. Of particular note are the cross-feeding activities that occur between the infant-type bifidobacterial strains $B$. $b i$ fidum PRL2010 and B. breve UCC2003, when these microorganisms are grown on sialyl lactose as the only carbon source [125]. Employing transcriptomic and functional genomic approaches, it was demonstrated that B. breve UCC2003 can cross-feed on the sialic acid released by the exosialidase activity of B. bifidum PRL2010 [125]. Other cross-feeding activities have been observed between a set of bifidobacterial strains such as B. bifidum PRL2010, B. breve 12L, B. adolescentis 22L, and Bifidobacterium thermophilum JCM7017, when cocultivated on plant-derived glycans such as starch and xylan [126]. Moreover, in vivo experiments using mice that had been administered B. bifidum PRL2010, B. longum subsp. infantis ATCC15697, B. adolescentis 22L, and B. breve 12L highlighted the existence of crossfeeding interactions between different bifidobacterial strains in the mammalian gut [127]. In fact, in these studies, the combination of transcriptomic and metagenomic approaches disclosed the evolution of the murine gut glycobiome across its enzymatic ability to degrade complex plant-derived carbohydrates such as xylo-oligosaccharides, arabinoxylan, starch, and host-glycan substrates. However, these are just some of the examples that confirm how bifidobacteria, in sharing glycan resources of the intestinal ecosystem, forge trophic relationships between intestinal microorganisms in mammals.

\section{Bifidobacteria as Possible Microbial Biomarkers of Health Predictor}

The human GIT consists of a complex and dynamic population of microorganisms, known as the gut microbiota, which have coevolved with their host [128]. The gut microbiota is considered an "essential organ" that offers many benefits to the host. In particular, gut bacteria are involved in many physiological functions such as strengthening gut integrity or shaping the intestinal epithelium [4,129], providing protection against pathogens [130,131], and influencing and regulating host immunity [4,61,132]. However, alterations of the intestinal microbiota can occur by changes in function, composition (dysbiosis), or host-microbiota interactions and they can be directly correlated with gastrointestinal diseases, such as inflammatory bowel disease (IBD), colorectal cancer, or irritable bowel syndrome (IBS) [133]. Furthermore, these alterations may be associated with other pathologies/disorders such as obesity, those affecting the respiratory tract (e.g., allergy, bronchial asthma, and cystic fibrosis) or the liver [133]. At the moment, several studies have focused on the effects and the role of bifidobacteria in those cases of dysbiosis [134,135].

In this context, the microbiota composition of necrotizing enterocolitis (NEC) patients, affected by a devastating intestinal disease most common in prematurely born infants, 
revealed an altered microbiota composition, in which bifidobacteria exhibit a very low abundance and prevalence during the first and second week of life, being distinctly different from a microbiota of a full-term infant $[136,137]$. In particular, in clinical trials that involved preterm neonates, based on the administration of B. breve YIT4010 and B. breve M-16V, separately, revealed that the treatment led to a significant reduction of infection and mortality rate [137]. These results are in accordance with Braga et al. [138], which showed that the treatment of NEC patients with the co-occurrence of B. breve Yakult and Lactobacillus casei plays an important role in reducing the incidence of this disease [137].

Furthermore, there is evidence of an alteration in the microbiota composition in other diseases such as in ulcerative colitis patients. In fact, a drastic reduction has been observed in the abundance of B. bifidum species in ulcerative colitis patients compared with healthy subjects [139]. Moreover, administration of B. bifidum PRL2010 to mice in a colitis model demonstrated a protective role in order to prevent and treat intestinal inflammation as well as re-establishment of intestinal microbiota homeostasis [139].

Studies on adenomatous polyps highlighted that abnormal tissue growth is associated with a high risk of developing colorectal cancer, based on its grade of dysplasia [135,140]. Interestingly, members of the Bifidobacterium genus are present in higher abundance in healthy marginal tissue when compared to colonic mucosa with polyp samples [135]. This differential bifidobacterial composition suggests the use of this genus as a biomarker for several disease conditions in biological samples [135].

\section{Conclusions}

Until today it has been widely demonstrated that bifidobacteria elicit positive effects on host health due to their metabolic and immunomodulatory activities. The study of complete bifidobacterial genomes and corresponding comparative analysis has allowed identification of various molecular mechanisms by which they interact with the host and are able to persist in the ecological niches they inhabit. The numerous benefits that have been associated with the presence of bifidobacteria, and that pertain to human physiology and the host immune system, have led to their commercial exploitation as probiotic ingredients in functional foods. Indeed, modulation of gut microbiota by means of prebiotics or probiotics could be one of the possible ways to combat intestinal disorders and improve health. However, the precise mechanism by which bifidobacteria are able to perform these important functions and are able to solicit immune responses is not fully understood. It is therefore of crucial importance that future studies fill this knowledge gap so that we will obtain a full understanding of their mode of action and allow targeted and specific applications to fully exploit their beneficial potential. Finally, despite the large knowledge that so far we have gained about bifidobacterial ecology and their genetic adaptation particularly to the human gut, much remains to be discovered about interactions and adaptations of bifidobacteria with the gut of other mammalian species.

Author Contributions: S.D., G.L. and F.T.: writing-original draft preparation. D.v.S. and M.V.: writing-review, editing, and conceptualization. All authors have read and agreed to the published version of the manuscript.

Funding: D.v.S. is member of APC microbiome Ireland which is funded by SFI through the Irish Government's National Development Plan (Grant Numbers SFI/12/RC/2273-P1 and SFI/12/RC/ 2273-P2).

Institutional Review Board Statement: Not applicable.

Acknowledgments: We thank GenProbio srl for financial support of the Laboratory of Probiogenomics.

Conflicts of Interest: The authors declare no conflict of interest. The company had no role in the design of the study; in the collection, analyses, or interpretation of data; in the writing of the manuscript, or in the decision to publish the results. 


\section{References}

1. Van Bergeijk, D.A.; Terlouw, B.R.; Medema, M.H.; van Wezel, G.P. Ecology and genomics of Actinobacteria: New concepts for natural product discovery. Nat. Rev. Microbiol. 2020, 18, 546-558. [CrossRef]

2. Ventura, M.; Canchaya, C.; Tauch, A.; Chandra, G.; Fitzgerald, G.F.; Chater, K.F.; van Sinderen, D. Genomics of Actinobacteria: Tracing the evolutionary history of an ancient phylum. Microbiol. Mol Biol. Rev. 2007, 71, 495-548. [CrossRef]

3. Tissier, H. Recherches Sur la Flore Intestinale des Nourrissons: (état Normal et Pathologique). Ph.D. Thesis, G. Carré et C. Naud, Paris, France, 1900; p. 253.

4. Alessandri, G.; Ossiprandi, M.C.; MacSharry, J.; van Sinderen, D.; Ventura, M. Bifidobacterial Dialogue With Its Human Host and Consequent Modulation of the Immune System. Front. Immunol. 2019, 10, 2348. [CrossRef]

5. Alberoni, D.; Gaggia, F.; Baffoni, L.; Modesto, M.M.; Biavati, B.; Di Gioia, D. Bifidobacterium xylocopae sp. nov. and Bifidobacterium aemilianum sp. nov., from the carpenter bee (Xylocopa violacea) digestive tract. Syst. Appl. Microbiol. 2019, 42, $205-216$. [CrossRef]

6. Duranti, S.; Lugli, G.A.; Napoli, S.; Anzalone, R.; Milani, C.; Mancabelli, L.; Alessandri, G.; Turroni, F.; Ossiprandi, M.C.; van Sinderen, D.; et al. Characterization of the phylogenetic diversity of five novel species belonging to the genus Bifidobacterium: Bifidobacterium castoris sp. nov., Bifidobacterium callimiconis sp. nov., Bifidobacterium goeldii sp. nov., Bifidobacterium samirii sp. nov. and Bifidobacterium dolichotidis sp. nov. Int. J. Syst. Evol. Microbiol. 2019, 69, 1288-1298. [CrossRef]

7. Lugli, G.A.; Mangifesta, M.; Duranti, S.; Anzalone, R.; Milani, C.; Mancabelli, L.; Alessandri, G.; Turroni, F.; Ossiprandi, M.C.; van Sinderen, D.; et al. Phylogenetic classification of six novel species belonging to the genus Bifidobacterium comprising Bifidobacterium anseris sp. nov., Bifidobacterium criceti sp. nov., Bifidobacterium imperatoris sp. nov., Bifidobacterium italicum sp. nov., Bifidobacterium margollesii sp. nov. and Bifidobacterium parmae sp. nov. Syst. Appl. Microbiol. 2018, 41, 173-183. [CrossRef]

8. Trovatelli, L.D.; Crociani, F.; Pedinotti, M.; Scardovi, V. Bifidobacterium pullorum sp. nov.: A new species isolated from chicken feces and a related group of bifidobacteria isolated from rabbit feces. Arch. Microbiol. 1974, 98, 187-198. [CrossRef]

9. Duranti, S.; Lugli, G.A.; Viappiani, A.; Mancabelli, L.; Alessandri, G.; Anzalone, R.; Longhi, G.; Milani, C.; Ossiprandi, M.C.; Turroni, F.; et al. Characterization of the phylogenetic diversity of two novel species belonging to the genus Bifidobacterium: Bifidobacterium cebidarum sp. nov. and Bifidobacterium leontopitheci sp. nov. Int. J. Syst. Evol. Microbiol. 2020, 70, $2288-2297$. [CrossRef]

10. Neuzil-Bunesova, V.; Lugli, G.A.; Modrackova, N.; Makovska, M.; Mrazek, J.; Mekadim, C.; Musilova, S.; Svobodova, I.; Spanek, R.; Ventura, M.; et al. Bifidobacterium canis sp. nov., a novel member of the Bifidobacterium pseudolongum phylogenetic group isolated from faeces of a dog (Canis lupus f. familiaris). Int. J. Syst. Evol. Microbiol. 2020, 70, 5040-5047. [CrossRef]

11. Modesto, M.; Puglisi, E.; Bonetti, A.; Michelini, S.; Spiezio, C.; Sandri, C.; Sgorbati, B.; Morelli, L.; Mattarelli, P. Bifidobacterium primatium sp. nov., Bifidobacterium scaligerum sp. nov., Bifidobacterium felsineum sp. nov. and Bifidobacterium simiarum sp. nov.: Four novel taxa isolated from the faeces of the cotton top tamarin (Saguinus oedipus) and the emperor tamarin (Saguinus imperator). Syst. Appl. Microbiol. 2018, 41, 593-603. [CrossRef]

12. Turroni, F; van Sinderen, D.; Ventura, M. Genomics and ecological overview of the genus Bifidobacterium. Int. J. Food Microbiol. 2011, 149, 37-44. [CrossRef] [PubMed]

13. Philippe, H.; Douady, C.J. Horizontal gene transfer and phylogenetics. Curr. Opin. Microbiol. 2003, 6, 498-505. [CrossRef] [PubMed]

14. Ventura, M.; Canchaya, C.; Casale, A.D.; Dellaglio, F.; Neviani, E.; Fitzgerald, G.F.; van Sinderen, D. Analysis of bifidobacterial evolution using a multilocus approach. Int. J. Syst. Evol. Microbiol. 2006, 56, 2783-2792. [CrossRef] [PubMed]

15. Lugli, G.A.; Milani, C.; Duranti, S.; Alessandri, G.; Turroni, F.; Mancabelli, L.; Tatoni, D.; Ossiprandi, M.C.; van Sinderen, D.; Ventura, M. Isolation of novel gut bifidobacteria using a combination of metagenomic and cultivation approaches. Genome Biol. 2019, 20, 96. [CrossRef] [PubMed]

16. Killer, J.; Kopecny, J.; Mrazek, J.; Koppova, I.; Havlik, J.; Benada, O.; Kott, T. Bifidobacterium actinocoloniiforme sp. nov. and Bifidobacterium bohemicum sp. nov., from the bumblebee digestive tract. Int. J. Syst. Evol. Microbiol. 2011, 61, 1315-1321. [CrossRef] [PubMed]

17. Reuter, G. [Comparative Studies on the Bifidus Flora in the Feces of Infants and Adults. With a Contribution to Classification and Nomenclature of Bifidus Strains]. Zentralbl. Bakteriol. Orig. 1963, 191, 486-507. [PubMed]

18. Michelini, S.; Modesto, M.; Filippini, G.; Spiezio, C.; Sandri, C.; Biavati, B.; Pisi, A.; Mattarelli, P. Bifidobacterium aerophilum sp. nov., Bifidobacterium avesanii sp. nov. and Bifidobacterium ramosum sp. nov.: Three novel taxa from the faeces of cotton-top tamarin (Saguinus oedipus L.). Syst. Appl. Microbiol. 2016, 39, 229-236. [CrossRef] [PubMed]

19. Toh, H.; Yamazaki, Y.; Tashiro, K.; Kawarai, S.; Oshima, K.; Nakano, A.; Kim, C.N.; Mimura, I.; Arakawa, K.; Iriki, A.; et al. Draft Genome Sequence of Bifidobacterium aesculapii DSM 26737T, Isolated from Feces of Baby Common Marmoset. Genome Announc. 2015, 3. [CrossRef]

20. Scardovi, V.; Sgorbati, B. Electrophoretic types of transaldolase, transketolase, and other enzymes in bifidobacteria. Antonie Van Leeuwenhoek 1974, 40, 427-440. [CrossRef]

21. Mitsuoka, T. [Comparative studies on bifidobacteria isolated from the alimentary tract of man and animals (including descriptions of bifidobacterium thermophilum nov. spec. and bifidobacterium pseudolongum nov. spec)]. Zentralbl. Bakteriol. Orig. 1969, 210, $52-64$. 
22. Masco, L.; Ventura, M.; Zink, R.; Huys, G.; Swings, J. Polyphasic taxonomic analysis of Bifidobacterium animalis and Bifidobacterium lactis reveals relatedness at the subspecies level: Reclassification of Bifidobacterium animalis as Bifidobacterium animalis subsp. animalis subsp. nov. and Bifidobacterium lactis as Bifidobacterium animalis subsp. lactis subsp. nov. Int. J. Syst. Evol. Microbiol. 2004, 54, 1137-1143. [CrossRef] [PubMed]

23. Pechar, R.; Killer, J.; Salmonova, H.; Geigerova, M.; Svejstil, R.; Svec, P.; Sedlacek, I.; Rada, V.; Benada, O. Bifidobacterium apri sp. nov., a thermophilic actinobacterium isolated from the digestive tract of wild pigs (Sus scrofa). Int. J. Syst. Evol. Microbiol. 2017, 67, 2349-2356. [CrossRef] [PubMed]

24. Laureys, D.; Cnockaert, M.; De Vuyst, L.; Vandamme, P. Bifidobacterium aquikefiri sp. nov., isolated from water kefir. Int. J. Syst. Evol. Microbiol. 2016, 66, 1281-1286. [CrossRef] [PubMed]

25. Scardovi, V.; Trovatelli, L.D. New species of bifid bacteria from Apis mellifica L. and Apis indica F. A contribution to the taxonomy and biochemistry of the genus Bifidobacterium. Zentralbl. Bakteriol. Parasitenkd. Infektionskr. Hyg. 1969, 123, 64-88. [PubMed]

26. Endo, A.; Futagawa-Endo, Y.; Schumann, P.; Pukall, R.; Dicks, L.M. Bifidobacterium reuteri sp. nov., Bifidobacterium callitrichos sp. nov., Bifidobacterium saguini sp. nov., Bifidobacterium stellenboschense sp. nov. and Bifidobacterium biavatii sp. nov. isolated from faeces of common marmoset (Callithrix jacchus) and red-handed tamarin (Saguinus midas). Syst. Appl. Microbiol. 2012, 35, 92-97. [CrossRef] [PubMed]

27. Killer, J.; Kopecny, J.; Mrazek, J.; Rada, V.; Benada, O.; Koppova, I.; Havlik, J.; Straka, J. Bifidobacterium bombi sp. nov., from the bumblebee digestive tract. Int. J. Syst. Evol. Microbiol. 2009, 59, 2020-2024. [CrossRef]

28. Scardovi, V.; Trovatelli, L.D.; Biavati, B.; Zani, G. Bifidobacterium cuniculi, Bifidobacterium choerinum, Bifido bacterium boum, and Bifidobacterium pseudocatenulatum: Four New Species and Their Deoxyribonucleic Acid Homology Relationships. Int. J. Bacteriol. 1979, 29, 291-311. [CrossRef]

29. Modesto, M.; Michelini, S.; Sansosti, M.C.; De Filippo, C.; Cavalieri, D.; Qvirist, L.; Andlid, T.; Spiezio, C.; Sandri, C.; Pascarelli, S.; et al. Bifidobacterium callitrichidarum sp. nov. from the faeces of the emperor tamarin (Saguinus imperator). Int. J. Syst. Evol. Microbiol. 2018, 68, 141-148. [CrossRef]

30. Scardovi, V.; Crociani, F. Bifidobacterium catenulatum, Bifidobacterium dentium, and Bifidobacterium angulatum: Three New Species and Their Deox y ribonucleic Acid Homology Relation ships. Int. J. Syst. Bacteriol. 1974, 24, 6-20. [CrossRef]

31. Morita, H.; Nakano, A.; Onoda, H.; Toh, H.; Oshima, K.; Takami, H.; Murakami, M.; Fukuda, S.; Takizawa, T.; Kuwahara, T.; et al. Bifidobacterium kashiwanohense sp. nov., isolated from healthy infant faeces. Int. J. Syst. Evol. Microbiol. 2011, 61, $2610-2615$. [CrossRef]

32. Modesto, M.; Michelini, S.; Oki, K.; Biavati, B.; Watanabe, K.; Mattarelli, P. Bifidobacterium catulorum sp. nov., a novel taxon from the faeces of the baby common marmoset (Callithrix jacchus). Int. J. Syst. Evol. Microbiol. 2018, 68, 575-581. [CrossRef] [PubMed]

33. Praet, J.; Meeus, I.; Cnockaert, M.; Aerts, M.; Smagghe, G.; Vandamme, P. Bifidobacterium commune sp. nov. isolated from the bumble bee gut. Antonie Van. Leeuwenhoek 2015, 107, 1307-1313. [CrossRef] [PubMed]

34. Delcenserie, V.; Gavini, F.; Beerens, H.; Tresse, O.; Franssen, C.; Daube, G. Description of a new species, Bifidobacterium crudilactis sp. nov., isolated from raw milk and raw milk cheeses. Syst. Appl. Microbiol. 2007, 30, 381-389. [CrossRef] [PubMed]

35. Michelini, S.; Modesto, M.; Pisi, A.M.; Filippini, G.; Sandri, C.; Spiezio, C.; Biavati, B.; Sgorbati, B.; Mattarelli, P. Bifidobacterium eulemuris sp. nov., isolated from faeces of black lemurs (Eulemur macaco). Int. J. Syst. Evol. Microbiol. 2016, 66, 1567-1576. [CrossRef]

36. Lauer, E. Bifidobacterium gallicum sp. nov. isolated from human feces. Int. J. Syst. Bacteriol. 1990, 40, 100-102. [CrossRef]

37. Michelini, S.; Oki, K.; Yanokura, E.; Shimakawa, Y.; Modesto, M.; Mattarelli, P.; Biavati, B.; Watanabe, K. Bifidobacterium myosotis sp. nov., Bifidobacterium tissieri sp. nov. and Bifidobacterium hapali sp. nov., isolated from faeces of baby common marmosets (Callithrix jacchus L.). Int. J. Syst. Evol. Microbiol. 2016, 66, 255-265. [CrossRef]

38. Modesto, M.; Watanabe, K.; Arita, M.; Satti, M.; Oki, K.; Sciavilla, P.; Patavino, C.; Camma, C.; Michelini, S.; Sgorbati, B.; et al. Bifidobacterium jacchi sp. nov., isolated from the faeces of a baby common marmoset (Callithrix jacchus). Int. J. Syst. Evol. Microbiol. 2019, 69, 2477-2485. [CrossRef]

39. Modesto, M.; Michelini, S.; Stefanini, I.; Sandri, C.; Spiezio, C.; Pisi, A.; Filippini, G.; Biavati, B.; Mattarelli, P. Bifidobacterium lemurum sp. nov., from faeces of the ring-tailed lemur (Lemur catta). Int. J. Syst. Evol. Microbiol. 2015, 65, 1726-1734. [CrossRef]

40. Matteuzzi, D.; Crociani, F.; Zani, G.; Trovatelli, L.D. Bifidobacterium suis n. sp.: A new species of the genus Bifidobacterium isolated from pig feces. Z. Allg. Mikrobiol. 1971, 11, 387-395. [CrossRef]

41. Biavati, B.; Mattarelli, P. Bifidobacterium ruminantium sp. nov. and Bifidobacterium merycicum sp. nov. from the rumens of cattle. Int. J. Syst. Bacteriol. 1991, 41, 163-168. [CrossRef]

42. Scardovi, V.; Trovatelli, L.D. Bifidobacterium animalis (Mitsuoka) comb. nov. and the "minimum" and "subtile" Groups of New Bifidobacteria Found in Sewage. Int. J. Syst. Bacteriol. 1974, 24, 21-28. [CrossRef]

43. Watanabe, K.; Makino, H.; Sasamoto, M.; Kudo, Y.; Fujimoto, J.; Demberel, S. Bifidobacterium mongoliense sp. nov., from airag, a traditional fermented mare's milk product from Mongolia. Int. J. Syst. Evol. Microbiol. 2009, 59, 1535-1540. [CrossRef]

44. Tsuchida, S.; Takahashi, S.; Nguema, P.P.M.; Fujita, S.; Kitahara, M.; Yamagiwa, J.; Ngomanda, A.; Ohkuma, M.; Ushida, K. Bifidobacterium moukalabense sp. nov., isolated from the faeces of wild west lowland gorilla (Gorilla gorilla gorilla). Int. J. Syst. Evol. Microbiol. 2014, 64, 449-455. [CrossRef] 
45. Modesto, M.; Satti, M.; Watanabe, K.; Scarafile, D.; Huang, C.H.; Liou, J.S.; Tamura, T.; Saito, S.; Watanabe, M.; Mori, K.; et al. Phylogenetic characterization of two novel species of the genus Bifidobacterium: Bifidobacterium saimiriisciurei sp. nov. and Bifidobacterium platyrrhinorum sp. nov. Syst. Appl. Microbiol. 2020, 43, 126111. [CrossRef] [PubMed]

46. Scardovi, V.; Trovatelli, L.D.; Crociani, F.; Sgorbati, B. Bifid bacteria in bovine rumen. New species of the genus Bifidobacterium: B. globosum n.sp. and B. ruminale n.sp. Arch. Mikrobiol. 1969, 68, 278-294. [CrossRef] [PubMed]

47. Simpson, P.J.; Ross, R.P.; Fitzgerald, G.F.; Stanton, C. Bifidobacterium psychraerophilum sp. nov. and Aeriscardovia aeriphila gen. nov., sp. nov., isolated from a porcine caecum. Int. J. Syst. Evol. Microbiol. 2004, 54, 401-406. [CrossRef] [PubMed]

48. Watabe, J.; Benno, Y.; Mitsuoka, T. Bijidobacterium gallinarum sp. nov.: A New Species Isolated from the Ceca of Chickens. Int. J. Syst. Bacterioly 1983, 33. [CrossRef]

49. Modesto, M.; Satti, M.; Watanabe, K.; Puglisi, E.; Morelli, L.; Huang, C.H.; Liou, J.S.; Miyashita, M.; Tamura, T.; Saito, S.; et al. Characterization of Bifidobacterium species in feaces of the Egyptian fruit bat: Description of B. vespertilionis sp. nov. and B. rousetti sp. nov. Syst. Appl. Microbiol. 2019, 42, 126017. [CrossRef]

50. Lugli, G.A.; Milani, C.; Turroni, F.; Duranti, S.; Ferrario, C.; Viappiani, A.; Mancabelli, L.; Mangifesta, M.; Taminiau, B.; Delcenserie, V.; et al. Investigation of the evolutionary development of the genus Bifidobacterium by comparative genomics. Appl. Environ. Microbiol. 2014, 80, 6383-6394. [CrossRef]

51. Hoyles, L.; Inganas, E.; Falsen, E.; Drancourt, M.; Weiss, N.; McCartney, A.L.; Collins, M.D. Bifidobacterium scardovii sp. nov., from human sources. Int. J. Syst. Evol. Microbiol. 2002, 52, 995-999. [CrossRef]

52. Zhu, L.; Li, W.; Dong, X. Species identification of genus Bifidobacterium based on partial HSP60 gene sequences and proposal of Bifidobacterium thermacidophilum subsp. porcinum subsp. nov. Int. J. Syst. Evol. Microbiol. 2003, 53, 1619-1623. [CrossRef] [PubMed]

53. Dong, X.; Xin, Y.; Jian, W.; Liu, X.; Ling, D. Bifidobacterium thermacidophilum sp. nov., isolated from an anaerobic digester. Int. J. Syst. Evol. Microbiol. 2000, 50 Pt 1, 119-125. [CrossRef] [PubMed]

54. Eckel, V.P.L.; Ziegler, L.M.; Vogel, R.F.; Ehrmann, M. Bifidobacterium tibiigranuli sp. nov. isolated from homemade water kefir. Int. J. Syst. Evol. Microbiol. 2020, 70, 1562-1570. [CrossRef] [PubMed]

55. Okamoto, M.; Benno, Y.; Leung, K.P.; Maeda, N. Bifidobacterium tsurumiense sp. nov., from hamster dental plaque. Int. J. Syst. Evol. Microbiol. 2008, 58, 144-148. [CrossRef] [PubMed]

56. Duranti, S.; Mangifesta, M.; Lugli, G.A.; Turroni, F.; Anzalone, R.; Milani, C.; Mancabelli, L.; Ossiprandi, M.C.; Ventura, M. Bifidobacterium vansinderenii sp. nov., isolated from faeces of emperor tamarin (Saguinus imperator). Int. J. Syst. Evol. Microbiol. 2017, 67, 3987-3995. [CrossRef]

57. Alessandri, G.; Milani, C.; Mancabelli, L.; Mangifesta, M.; Lugli, G.A.; Viappiani, A.; Duranti, S.; Turroni, F.; Ossiprandi, M.C.; van Sinderen, D.; et al. The impact of human-facilitated selection on the gut microbiota of domesticated mammals. FEMS Microbiol. Ecol. 2019, 95. [CrossRef]

58. Milani, C.; Mangifesta, M.; Mancabelli, L.; Lugli, G.A.; James, K.; Duranti, S.; Turroni, F.; Ferrario, C.; Ossiprandi, M.C.; van Sinderen, D.; et al. Unveiling bifidobacterial biogeography across the mammalian branch of the tree of life. ISME J. 2017, 11, 2834-2847. [CrossRef]

59. Wong, C.B.; Odamaki, T.; Xiao, J.Z. Insights into the reason of Human-Residential Bifidobacteria (HRB) being the natural inhabitants of the human gut and their potential health-promoting benefits. FEMS Microbiol. Rev. 2020, 44, 369-385. [CrossRef]

60. Bottacini, F.; Ventura, M.; van Sinderen, D.; O'Connell Motherway, M. Diversity, ecology and intestinal function of bifidobacteria. Microb. Cell. Fact. 2014, 13 (Suppl. 1), S4. [CrossRef]

61. Ruiz, L.; Delgado, S.; Ruas-Madiedo, P.; Sanchez, B.; Margolles, A. Bifidobacteria and Their Molecular Communication with the Immune System. Front. Microbiol. 2017, 8, 2345. [CrossRef]

62. Turroni, F.; Peano, C.; Pass, D.A.; Foroni, E.; Severgnini, M.; Claesson, M.J.; Kerr, C.; Hourihane, J.; Murray, D.; Fuligni, F.; et al. Diversity of bifidobacteria within the infant gut microbiota. PLoS. ONE 2012, 7, e36957. [CrossRef] [PubMed]

63. Palmer, C.; Bik, E.M.; DiGiulio, D.B.; Relman, D.A.; Brown, P.O. Development of the human infant intestinal microbiota. PLoS Biol. 2007, 5, e177. [CrossRef] [PubMed]

64. Koenig, J.E.; Spor, A.; Scalfone, N.; Fricker, A.D.; Stombaugh, J.; Knight, R.; Angenent, L.T.; Ley, R.E. Succession of microbial consortia in the developing infant gut microbiome. Proc. Natl. Acad. Sci. USA 2011, 108 (Suppl. 1), 4578-4585. [CrossRef] [PubMed]

65. Avershina, E.; Lundgard, K.; Sekelja, M.; Dotterud, C.; Storro, O.; Oien, T.; Johnsen, R.; Rudi, K. Transition from infant- to adult-like gut microbiota. Environ. Microbiol. 2016, 18, 2226-2236. [CrossRef]

66. Nuriel-Ohayon, M.; Neuman, H.; Koren, O. Microbial Changes during Pregnancy, Birth, and Infancy. Front. Microbiol. 2016, 7, 1031. [CrossRef]

67. Rautava, S.; Luoto, R.; Salminen, S.; Isolauri, E. Microbial contact during pregnancy, intestinal colonization and human disease. Nat. Rev. Gastroenterol. Hepatol. 2012, 9, 565-576. [CrossRef]

68. Milani, C.; Mancabelli, L.; Lugli, G.A.; Duranti, S.; Turroni, F.; Ferrario, C.; Mangifesta, M.; Viappiani, A.; Ferretti, P.; Gorfer, V.; et al. Exploring Vertical Transmission of Bifidobacteria from Mother to Child. Appl. Environ. Microbiol. 2015, 81, 7078-7087. [CrossRef] 
69. Sela, D.A.; Chapman, J.; Adeuya, A.; Kim, J.H.; Chen, F.; Whitehead, T.R.; Lapidus, A.; Rokhsar, D.S.; Lebrilla, C.B.; German, J.B.; et al. The genome sequence of Bifidobacterium longum subsp. infantis reveals adaptations for milk utilization within the infant microbiome. Proc. Natl. Acad. Sci. USA 2008, 105, 18964-18969. [CrossRef]

70. Ishikawa, E.; Matsuki, T.; Kubota, H.; Makino, H.; Sakai, T.; Oishi, K.; Kushiro, A.; Fujimoto, J.; Watanabe, K.; Watanuki, M.; et al. Ethnic diversity of gut microbiota: Species characterization of Bacteroides fragilis group and genus Bifidobacterium in healthy Belgian adults, and comparison with data from Japanese subjects. J. Biosci. Bioeng. 2013, 116, 265-270. [CrossRef]

71. Odamaki, T.; Bottacini, F.; Kato, K.; Mitsuyama, E.; Yoshida, K.; Horigome, A.; Xiao, J.Z.; van Sinderen, D. Genomic diversity and distribution of Bifidobacterium longum subsp. longum across the human lifespan. Sci. Rep. 2018, 8, 85. [CrossRef]

72. Eckburg, P.B.; Bik, E.M.; Bernstein, C.N.; Purdom, E.; Dethlefsen, L.; Sargent, M.; Gill, S.R.; Nelson, K.E.; Relman, D.A. Diversity of the human intestinal microbial flora. Science 2005, 308, 1635-1638. [CrossRef] [PubMed]

73. Turroni, F.; Foroni, E.; Pizzetti, P.; Giubellini, V.; Ribbera, A.; Merusi, P.; Cagnasso, P.; Bizzarri, B.; de'Angelis, G.L.; Shanahan, F.; et al. Exploring the diversity of the bifidobacterial population in the human intestinal tract. Appl. Environ. Microbiol. 2009, 75, 1534-1545. [CrossRef] [PubMed]

74. O'Callaghan, A.; van Sinderen, D. Bifidobacteria and Their Role as Members of the Human Gut Microbiota. Front. Microbiol. 2016, 7, 925. [CrossRef]

75. Jacob, R.A. Folate, DNA methylation, and gene expression: Factors of nature and nurture. Am. J. Clin. Nutr. 2000, 72, 903-904. [CrossRef] [PubMed]

76. Lucock, M. Folic acid: Nutritional biochemistry, molecular biology, and role in disease processes. Mol. Genet. Metab. 2000, 71, 121-138. [CrossRef] [PubMed]

77. Ganesan, B.; Weimer, B.C.; Pinzon, J.; Dao Kong, N.; Rompato, G.; Brothersen, C.; McMahon, D.J. Probiotic bacteria survive in Cheddar cheese and modify populations of other lactic acid bacteria. J. Appl. Microbiol. 2014, 116, 1642-1656. [CrossRef] [PubMed]

78. Heller, K.J. Probiotic bacteria in fermented foods: Product characteristics and starter organisms. Am. J. Clin. Nutr. 2001, 73, 374S-379S. [CrossRef]

79. Huang, J.S.; Bousvaros, A.; Lee, J.W.; Diaz, A.; Davidson, E.J. Efficacy of probiotic use in acute diarrhea in children: A metaanalysis. Dig. Dis. Sci. 2002, 47, 2625-2634. [CrossRef]

80. Allen, S.J.; Okoko, B.; Martinez, E.; Gregorio, G.; Dans, L.F. Probiotics for treating infectious diarrhoea. Cochrane Database Syst. Rev. 2004, CD003048. [CrossRef]

81. Saavedra, J.M.; Bauman, N.A.; Oung, I.; Perman, J.A.; Yolken, R.H. Feeding of Bifidobacterium bifidum and Streptococcus thermophilus to infants in hospital for prevention of diarrhoea and shedding of rotavirus. Lancet 1994, 344, 1046-1049. [CrossRef]

82. Turroni, F.; Bottacini, F.; Foroni, E.; Mulder, I.; Kim, J.H.; Zomer, A.; Sanchez, B.; Bidossi, A.; Ferrarini, A.; Giubellini, V.; et al. Genome analysis of Bifidobacterium bifidum PRL2010 reveals metabolic pathways for host-derived glycan foraging. Proc. Natl. Acad. Sci. USA 2010, 107, 19514-19519. [CrossRef] [PubMed]

83. Duranti, S.; Milani, C.; Lugli, G.A.; Mancabelli, L.; Turroni, F.; Ferrario, C.; Mangifesta, M.; Viappiani, A.; Sanchez, B.; Margolles, A.; et al. Evaluation of genetic diversity among strains of the human gut commensal Bifidobacterium adolescentis. Sci. Rep. 2016, 6, 23971. [CrossRef] [PubMed]

84. Duranti, S.; Milani, C.; Lugli, G.A.; Turroni, F.; Mancabelli, L.; Sanchez, B.; Ferrario, C.; Viappiani, A.; Mangifesta, M.; Mancino, W.; et al. Insights from genomes of representatives of the human gut commensal Bifidobacterium bifidum. Environ. Microbiol. 2015, 17, 2515-2531. [CrossRef] [PubMed]

85. Zabel, B.E.; Gerdes, S.; Evans, K.C.; Nedveck, D.; Singles, S.K.; Volk, B.; Budinoff, C. Strain-specific strategies of 2'-fucosyllactose, 3-fucosyllactose, and difucosyllactose assimilation by Bifidobacterium longum subsp. infantis Bi-26 and ATCC 15697. Sci. Rep. 2020, 10, 15919. [CrossRef]

86. O'Connell Motherway, M.; Fitzgerald, G.F.; Neirynck, S.; Ryan, S.; Steidler, L.; van Sinderen, D. Characterization of ApuB, an extracellular type II amylopullulanase from Bifidobacterium breve UCC2003. Appl. Environ. Microbiol. 2008, 74, 6271-6279. [CrossRef]

87. Turroni, F.; Milani, C.; Duranti, S.; Mahony, J.; van Sinderen, D.; Ventura, M. Glycan Utilization and Cross-Feeding Activities by Bifidobacteria. Trends Microbiol. 2018, 26, 339-350. [CrossRef]

88. Duranti, S.; Turroni, F.; Lugli, G.A.; Milani, C.; Viappiani, A.; Mangifesta, M.; Gioiosa, L.; Palanza, P.; van Sinderen, D.; Ventura, M. Genomic characterization and transcriptional studies of the starch-utilizing strain Bifidobacterium adolescentis 22L. Appl. Environ. Microbiol. 2014, 80, 6080-6090. [CrossRef]

89. Ventura, M.; Turroni, F.; Motherway, M.O.; MacSharry, J.; van Sinderen, D. Host-microbe interactions that facilitate gut colonization by commensal bifidobacteria. Trends Microbiol. 2012, 20, 467-476. [CrossRef]

90. Bottacini, F.; van Sinderen, D.; Ventura, M. Omics of bifidobacteria: Research and insights into their health-promoting activities Biochem. J. 2017, 474, 4137-4152. [CrossRef]

91. Tremaroli, V.; Backhed, F. Functional interactions between the gut microbiota and host metabolism. Nature 2012, 489, 242-249. [CrossRef]

92. Agus, A.; Planchais, J.; Sokol, H. Gut Microbiota Regulation of Tryptophan Metabolism in Health and Disease. Cell Host Microbe 2018, 23, 716-724. [CrossRef] [PubMed] 
93. Sakurai, T.; Odamaki, T.; Xiao, J.Z. Production of Indole-3-Lactic Acid by Bifidobacterium Strains Isolated fromHuman Infants. Microorganisms 2019, 7, 340. [CrossRef] [PubMed]

94. Wong, C.B.; Tanaka, A.; Kuhara, T.; Xiao, J.Z. Potential Effects of Indole-3-Lactic Acid, a Metabolite of Human Bifidobacteria, on NGF-induced Neurite Outgrowth in PC12 Cells. Microorganisms 2020, 8, 398. [CrossRef] [PubMed]

95. Krishnan, S.; Ding, Y.; Saedi, N.; Choi, M.; Sridharan, G.V.; Sherr, D.H.; Yarmush, M.L.; Alaniz, R.C.; Jayaraman, A.; Lee, K. Gut Microbiota-Derived Tryptophan Metabolites Modulate Inflammatory Response in Hepatocytes and Macrophages. Cell Rep. 2018, 23, 1099-1111. [CrossRef] [PubMed]

96. Hwang, I.K.; Yoo, K.Y.; Li, H.; Park, O.K.; Lee, C.H.; Choi, J.H.; Jeong, Y.G.; Lee, Y.L.; Kim, Y.M.; Kwon, Y.G.; et al. Indole3-propionic acid attenuates neuronal damage and oxidative stress in the ischemic hippocampus. J. Neurosci. Res. 2009, 87, 2126-2137. [CrossRef] [PubMed]

97. Foroni, E.; Serafini, F.; Amidani, D.; Turroni, F.; He, F.; Bottacini, F.; O'Connell Motherway, M.; Viappiani, A.; Zhang, Z.; Rivetti, C.; et al. Genetic analysis and morphological identification of pilus-like structures in members of the genus Bifidobacterium. Microb. Cell Fact. 2011, 10 (Suppl. 1), S16. [CrossRef]

98. Turroni, F.; Serafini, F.; Foroni, E.; Duranti, S.; O'Connell Motherway, M.; Taverniti, V.; Mangifesta, M.; Milani, C.; Viappiani, A.; Roversi, T.; et al. Role of sortase-dependent pili of Bifidobacterium bifidum PRL2010 in modulating bacterium-host interactions. Proc. Natl. Acad. Sci. USA 2013, 110, 11151-11156. [CrossRef]

99. O'Connell Motherway, M.; Zomer, A.; Leahy, S.C.; Reunanen, J.; Bottacini, F.; Claesson, M.J.; O’Brien, F.; Flynn, K.; Casey, P.G.; Munoz, J.A.; et al. Functional genome analysis of Bifidobacterium breve UCC2003 reveals type IVb tight adherence (Tad) pili as an essential and conserved host-colonization factor. Proc. Natl. Acad. Sci. USA 2011, 108, 11217-11222. [CrossRef]

100. Scott, J.R.; Zahner, D. Pili with strong attachments: Gram-positive bacteria do it differently. Mol. Microbiol. 2006, 62, 320-330. [CrossRef]

101. Milani, C.; Mangifesta, M.; Mancabelli, L.; Lugli, G.A.; Mancino, W.; Viappiani, A.; Faccini, A.; van Sinderen, D.; Ventura, M.; Turroni, F. The Sortase-Dependent Fimbriome of the Genus Bifidobacterium: Extracellular Structures with Potential To Modulate Microbe-Host Dialogue. Appl. Environ. Microbiol. 2017, 83. [CrossRef]

102. Tomich, M.; Planet, P.J.; Figurski, D.H. The tad locus: Postcards from the widespread colonization island. Nat. Rev. Microbiol. 2007, 5, 363-375. [CrossRef] [PubMed]

103. O'Connell Motherway, M.; Houston, A.; O'Callaghan, G.; Reunanen, J.; O’Brien, F.; O’Driscoll, T.; Casey, P.G.; de Vos, W.M.; van Sinderen, D.; Shanahan, F. A Bifidobacterial pilus-associated protein promotes colonic epithelial proliferation. Mol. Microbiol. 2019, 111, 287-301. [CrossRef] [PubMed]

104. Potempa, J.; Korzus, E.; Travis, J. The serpin superfamily of proteinase inhibitors: Structure, function, and regulation. J. Biol. Chem. 1994, 269, 15957-15960. [PubMed]

105. Turroni, F.; Foroni, E.; O'Connell Motherway, M.; Bottacini, F.; Giubellini, V.; Zomer, A.; Ferrarini, A.; Delledonne, M.; Zhang, Z.; van Sinderen, D.; et al. Characterization of the serpin-encoding gene of Bifidobacterium breve 210B. Appl. Environ. Microbiol. 2010, 76, 3206-3219. [CrossRef]

106. Alvarez-Martin, P.; O'Connell Motherway, M.; Turroni, F.; Foroni, E.; Ventura, M.; van Sinderen, D. A two-component regulatory system controls autoregulated serpin expression in Bifidobacterium breve UCC2003. Appl. Environ. Microbiol. 2012, 78, 7032-7041. [CrossRef]

107. Alvarez-Martin, P.; Fernandez, M.; O'Connell-Motherway, M.; O'Connell, K.J.; Sauvageot, N.; Fitzgerald, G.F.; MacSharry, J.; Zomer, A.; van Sinderen, D. A conserved two-component signal transduction system controls the response to phosphate starvation in Bifidobacterium breve UCC2003. Appl. Environ. Microbiol. 2012, 78, 5258-5269. [CrossRef]

108. Ivanov, D.; Emonet, C.; Foata, F.; Affolter, M.; Delley, M.; Fisseha, M.; Blum-Sperisen, S.; Kochhar, S.; Arigoni, F. A serpin from the gut bacterium Bifidobacterium longum inhibits eukaryotic elastase-like serine proteases. J. Biol. Chem. 2006, 281, 17246-17252. [CrossRef]

109. Ferrario, C.; Milani, C.; Mancabelli, L.; Lugli, G.A.; Duranti, S.; Mangifesta, M.; Viappiani, A.; Turroni, F.; Margolles, A.; Ruas-Madiedo, P.; et al. Modulation of the eps-ome transcription of bifidobacteria through simulation of human intestinal environment. FEMS Microbiol. Ecol. 2016, 92, fiw056. [CrossRef]

110. Turroni, F.; Ventura, M.; Butto, L.F.; Duranti, S.; O’Toole, P.W.; Motherway, M.O.; van Sinderen, D. Molecular dialogue between the human gut microbiota and the host: A Lactobacillus and Bifidobacterium perspective. Cell. Mol. Life Sci. 2014, 71, 183-203. [CrossRef]

111. Horn, N.; Wegmann, U.; Dertli, E.; Mulholland, F.; Collins, S.R.; Waldron, K.W.; Bongaerts, R.J.; Mayer, M.J.; Narbad, A. Spontaneous mutation reveals influence of exopolysaccharide on Lactobacillus johnsonii surface characteristics. PLoS ONE 2013, 8, e59957. [CrossRef]

112. Fanning, S.; Hall, L.J.; van Sinderen, D. Bifidobacterium breve UCC2003 surface exopolysaccharide production is a beneficial trait mediating commensal-host interaction through immune modulation and pathogen protection. Gut Microbes 2012, 3, 420-425. [CrossRef] [PubMed]

113. Ruas-Madiedo, P.; Gueimonde, M.; Arigoni, F.; de los Reyes-Gavilan, C.G.; Margolles, A. Bile affects the synthesis of exopolysaccharides by Bifidobacterium animalis. Appl. Environ. Microbiol. 2009, 75, 1204-1207. [CrossRef] [PubMed] 
114. Fanning, S.; Hall, L.J.; Cronin, M.; Zomer, A.; MacSharry, J.; Goulding, D.; Motherway, M.O.; Shanahan, F.; Nally, K.; Dougan, G.; et al. Bifidobacterial surface-exopolysaccharide facilitates commensal-host interaction through immune modulation and pathogen protection. Proc. Natl. Acad. Sci. USA 2012, 109, 2108-2113. [CrossRef] [PubMed]

115. Altmann, F.; Kosma, P.; O'Callaghan, A.; Leahy, S.; Bottacini, F.; Molloy, E.; Plattner, S.; Schiavi, E.; Gleinser, M.; Groeger, D.; et al. Genome Analysis and Characterisation of the Exopolysaccharide Produced by Bifidobacterium longum subsp. longum 35624 . PLoS ONE 2016, 11, e0162983. [CrossRef]

116. Schiavi, E.; Gleinser, M.; Molloy, E.; Groeger, D.; Frei, R.; Ferstl, R.; Rodriguez-Perez, N.; Ziegler, M.; Grant, R.; Moriarty, T.F.; et al. The Surface-Associated Exopolysaccharide of Bifidobacterium longum 35624 Plays an Essential Role in Dampening Host Proinflammatory Responses and Repressing Local TH17 Responses. Appl. Environ. Microbiol. 2016, 82, 7185-7196. [CrossRef]

117. den Besten, G.; van Eunen, K.; Groen, A.K.; Venema, K.; Reijngoud, D.J.; Bakker, B.M. The role of short-chain fatty acids in the interplay between diet, gut microbiota, and host energy metabolism. J. Lipid Res. 2013, 54, 2325-2340. [CrossRef]

118. Ratajczak, W.; Ryl, A.; Mizerski, A.; Walczakiewicz, K.; Sipak, O.; Laszczynska, M. Immunomodulatory potential of gut microbiome-derived short-chain fatty acids (SCFAs). Acta Biochim. Pol. 2019, 66, 1-12. [CrossRef]

119. Rios-Covian, D.; Ruas-Madiedo, P.; Margolles, A.; Gueimonde, M.; de Los Reyes-Gavilan, C.G.; Salazar, N. Intestinal Short Chain Fatty Acids and their Link with Diet and Human Health. Front. Microbiol. 2016, 7, 185. [CrossRef]

120. Riviere, A.; Selak, M.; Lantin, D.; Leroy, F.; De Vuyst, L. Bifidobacteria and Butyrate-Producing Colon Bacteria: Importance and Strategies for Their Stimulation in the Human Gut. Front. Microbiol. 2016, 7, 979. [CrossRef]

121. Riviere, A.; Gagnon, M.; Weckx, S.; Roy, D.; De Vuyst, L. Mutual Cross-Feeding Interactions between Bifidobacterium longum subsp. longum NCC2705 and Eubacterium rectale ATCC 33656 Explain the Bifidogenic and Butyrogenic Effects of Arabinoxylan Oligosaccharides. Appl. Environ. Microbiol. 2015, 81, 7767-7781. [CrossRef]

122. Falony, G.; Calmeyn, T.; Leroy, F.; De Vuyst, L. Coculture fermentations of Bifidobacterium species and Bacteroides thetaiotaomicron reveal a mechanistic insight into the prebiotic effect of inulin-type fructans. Appl. Environ. Microbiol. 2009, 75, $2312-2319$. [CrossRef] [PubMed]

123. Rios-Covian, D.; Sanchez, B.; Salazar, N.; Martinez, N.; Redruello, B.; Gueimonde, M.; de Los Reyes-Gavilan, C.G. Different metabolic features of Bacteroides fragilis growing in the presence of glucose and exopolysaccharides of bifidobacteria. Front. Microbiol. 2015, 6, 825. [CrossRef]

124. Rios-Covian, D.; Gueimonde, M.; Duncan, S.H.; Flint, H.J.; de los Reyes-Gavilan, C.G. Enhanced butyrate formation by crossfeeding between Faecalibacterium prausnitzii and Bifidobacterium adolescentis. FEMS Microbiol. Lett. 2015, 362. [CrossRef] [PubMed]

125. Egan, M.; O'Connell Motherway, M.; Ventura, M.; van Sinderen, D. Metabolism of sialic acid by Bifidobacterium breve UCC2003. Appl. Environ. Microbiol. 2014, 80, 4414-4426. [CrossRef] [PubMed]

126. Turroni, F.; Ozcan, E.; Milani, C.; Mancabelli, L.; Viappiani, A.; van Sinderen, D.; Sela, D.A.; Ventura, M. Glycan cross-feeding activities between bifidobacteria under in vitro conditions. Front. Microbiol. 2015, 6, 1030. [CrossRef] [PubMed]

127. Turroni, F.; Milani, C.; Duranti, S.; Mancabelli, L.; Mangifesta, M.; Viappiani, A.; Lugli, G.A.; Ferrario, C.; Gioiosa, L.; Ferrarini, A.; et al. Deciphering bifidobacterial-mediated metabolic interactions and their impact on gut microbiota by a multiomics approach. ISME J. 2016, 10, 1656-1668. [CrossRef] [PubMed]

128. Wu, H.J.; Wu, E. The role of gut microbiota in immune homeostasis and autoimmunity. Gut Microbes 2012, 3, 4-14. [CrossRef]

129. Moens, E.; Veldhoen, M. Epithelial barrier biology: Good fences make good neighbours. Immunology 2012, 135, 1-8. [CrossRef]

130. Baumler, A.J.; Sperandio, V. Interactions between the microbiota and pathogenic bacteria in the gut. Nature 2016, 535, 85-93. [CrossRef]

131. Pickard, J.M.; Zeng, M.Y.; Caruso, R.; Nunez, G. Gut microbiota: Role in pathogen colonization, immune responses, and inflammatory disease. Immunol. Rev. 2017, 279, 70-89. [CrossRef]

132. Gensollen, T.; Iyer, S.S.; Kasper, D.L.; Blumberg, R.S. How colonization by microbiota in early life shapes the immune system. Science 2016, 352, 539-544. [CrossRef] [PubMed]

133. Tojo, R.; Suarez, A.; Clemente, M.G.; de los Reyes-Gavilan, C.G.; Margolles, A.; Gueimonde, M.; Ruas-Madiedo, P. Intestinal microbiota in health and disease: Role of bifidobacteria in gut homeostasis. World J. Gastroenterol. 2014, 20, 15163-15176. [CrossRef] [PubMed]

134. Wu, G.D.; Lewis, J.D. Analysis of the human gut microbiome and association with disease. Clin. Gastroenterol. Hepatol. 2013, 11, 774-777. [CrossRef] [PubMed]

135. Mangifesta, M.; Mancabelli, L.; Milani, C.; Gaiani, F.; de'Angelis, N.; de'Angelis, G.L.; van Sinderen, D.; Ventura, M.; Turroni, F. Mucosal microbiota of intestinal polyps reveals putative biomarkers of colorectal cancer. Sci. Rep. 2018, 8, 13974. [CrossRef] [PubMed]

136. Khailova, L.; Mount Patrick, S.K.; Arganbright, K.M.; Halpern, M.D.; Kinouchi, T.; Dvorak, B. Bifidobacterium bifidum reduces apoptosis in the intestinal epithelium in necrotizing enterocolitis. Am. J. Physiol. Gastrointest. Liver Physiol. 2010, 299, G1118-G1127. [CrossRef]

137. Bozzi Cionci, N.; Baffoni, L.; Gaggia, F.; Di Gioia, D. Therapeutic Microbiology: The Role of Bifidobacterium breve as Food Supplement for the Prevention/Treatment of Paediatric Diseases. Nutrients 2018, 10, 1723. [CrossRef] [PubMed] 
138. Braga, T.D.; da Silva, G.A.; de Lira, P.I.; de Carvalho Lima, M. Efficacy of Bifidobacterium breve and Lactobacillus casei oral supplementation on necrotizing enterocolitis in very-low-birth-weight preterm infants: A double-blind, randomized, controlled trial. Am. J. Clin. Nutr. 2011, 93, 81-86. [CrossRef]

139. Duranti, S.; Gaiani, F.; Mancabelli, L.; Milani, C.; Grandi, A.; Bolchi, A.; Santoni, A.; Lugli, G.A.; Ferrario, C.; Mangifesta, M.; et al. Elucidating the gut microbiome of ulcerative colitis: Bifidobacteria as novel microbial biomarkers. FEMS Microbiol. Ecol. $2016,92$. [CrossRef]

140. Leslie, A.; Carey, F.A.; Pratt, N.R.; Steele, R.J. The colorectal adenoma-carcinoma sequence. Br. J. Surg. 2002, 89, 845-860. [CrossRef] 